\title{
Analisis Parameter Jaringan Saraf Tiruan Menggunakan Metode Backpropagation pada Pengenalan Pola Angka
}

\author{
Haryanto $^{1^{*}}$ \\ ${ }^{1}$ Program Studi Informatika, Universitas Widya Dharma Pontianak \\ *haryanto@widyadharma.ac.id
}

\begin{abstract}
Artificial Neural Networks is a scientific discipline in artificial intelligence that is widely used today. Although there are many promising applications that can be performed by artificial neural networks, they also have some general limitations. One of them is the inaccuracy of the results obtained. Therefore, the authors designed an artificial neural network application system for number recognition using the Backpropagation method with the aim of producing an application that implements an artificial neural network using the Backpropagation method to convert numeric writing in the form of images to digital with accurate results. From the results of research conducted to design numerical recognition neural networks with accurate results, it is necessary to pay attention to the input data used, the parameters that are set, and the conditions when the iteration is complete.

Keywords: Artificial Neural Networks, backpropagation, pattern recognition
\end{abstract}

\begin{abstract}
Abstrak
Jaringan Saraf Tiruan merupakan suatu disiplin ilmu dalam kecerdasan buatan yang banyak digunakan saat ini. Meskipun banyak aplikasi menjanjikan yang dapat dilakukan oleh jaringan saraf tiruan, namun jaringan saraf tiruan juga memiliki beberapa keterbatasan umum. salah satunya adalah ketidakakuratan hasil yang diperoleh. Oleh sebab itu, penulis merancang suatu sistem penerapan jaringan saraf tiruan untuk pengenalan angka menggunakan metode Backpropagation dengan tujuan untuk menghasilkan sebuah aplikasi yang menerapkan jaringan saraf tiruan dengan menggunakan metode Backpropagation untuk mengkonversi tulisan angka berupa citra menjadi digital dengan hasil yang akurat. Dari hasil penelitian yang dilakukan untuk merancang jaringan saraf tiruan pengenalan angka dengan hasil yang akurat, perlu diperhatikan data input yang digunakan, parameter yang diset, serta kondisi saat iterasi selesai dilakukan.
\end{abstract}

Kata kunci: jaringan saraf tiruan, backpropagation, pengenalan pola angka

1. Pendahuluan

Didukung dengan perkembangan hardware dan software yang sangat beragam, Artificial Intelligence (AI) telah menghasilkan banyak produk yang sangat penting dan berguna bagi kehidupan manusia [1]. Salah satu produk AI yang banyak digunakan saat ini adalah pengenalan pola. Pengenalan Pola (Pattern Recognition) adalah penentuan suatu objek fisik atau kejadian ke dalam salah satu atau beberapa kategori [2]. Pengenalan pola mengalami banyak kemajuan dan semakin banyak dipakai untuk memecahakan suatu masalah. Pengenalan pola dipakai untuk mengenali tulisan tangan, tanda tangan, gambar dan sebagainya. Tahapan dalam pengenalan pola terdiri dari prapengolahan, ekstraksi ciri, dan klasifikasi. Tahapan tersebut dapat dilakukan dengan menerapkan salah satu metode pendekatan yang juga dapat digunakan untuk sistem pengenalan pola karakter dengan menggunakan metode Jaringan Saraf Tiruan (JST)[3]. Jaringan saraf tiruan memiliki beberapa metode atau algoritma yang dapat digunakan untuk mengklarifikasi atau mengenali suatu tipe pola, salah satunya adalah propagasi balik (Backpropagation).

Backpropagation merupakan perkembangan dari jaringan saraf tiruan 
dengan metode Perceptron yang masih menggunakan jaringan layar tunggal. Metode Backpropagation menggunakan jaringan saraf tiruan dengan banyak layer dan menggunakan error output untuk mengolah nilai bobot-bobot awalnya, sehingga metode Backpropagation dapat menanggulangi keterbatasan pola yang biasa terjadi dalam jaringan saraf tunggal.

Untuk menghasilkan jaringan saraf tiruan pengenalan pola yang baik, perlu diperhatikan seberapa besar tingkat kesalahan dalam mengenali suatu pola. Sebab semakin kecil tingkat kesalahan, maka semakin baik jaringan saraf tiruan yang telah dibuat [4]. Penentuan parameter pada jaringan saraf tiruan digunakan untuk menemukan model terbaik untuk melakukan pengenalan pola, yaitu dengan mencari nilai terbaik dari setiap parameter yang ada. Penentuan parameter jaringan saraf tiruan pada penelitian ini berdasarkan pada Epoch, kinerja tujuan, learning rate, maksimum kegagalan, gradient minimum, dan momentum.

\section{Metoda Penelitian}

Dalam membangun sistem jaringan saraf tiruan pengenalan angka terdapat tiga proses yang harus dilakukan, yaitu image preprocessing, pelatihan, dan pengenalan.

\subsection{Proses Image Preprocessing}

Tahap ini akan dilakukan bertujuan untuk mengenali pola pada citra digital, sehingga citra tersebut dapat diproses ke tahap selanjutnya. Pada tahap ini akan dilakukan pengolahan citra terhadap citra yang akan dikenali. Citra truecolor akan diubah menjadi citra biner, agar lebih mudah dikenali.

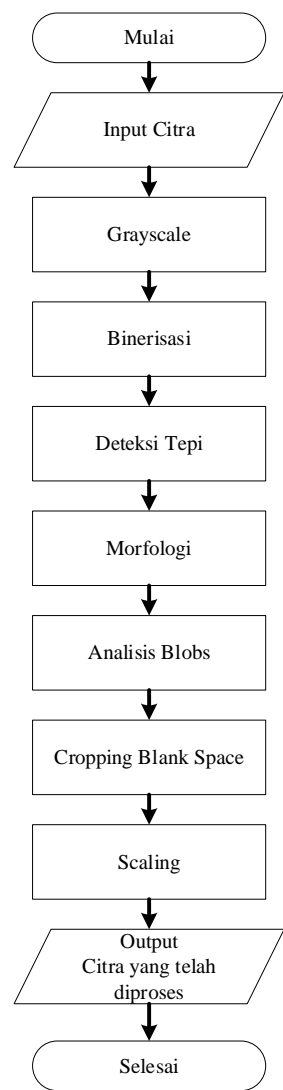

Gambar 1. Flowchart Prosedur Image Preprocessing

Proses image preprocessing dimulai dengan mengambil citra untuk dilakukan proses image preprocessing. Setelah citra diambil, dilakukan konversi citra menjadi citra biner, dengan terlebih dahulu dikonversi menjadi citra grayscale. Seteleh dikonversi, dilakukan teknik morfologi dan analisis blobs untuk menentukan letak gambar. Dari hasil analisis blobs dapat dilakukan cropping untuk menghilangkan baris-baris kosong di kiri, kanan, atas dan bawah citra angka yang akan diambil. Setelah dilakukan cropping, selanjutnya gambar akan dilakukan perubahan ukuran citra. Citra akan diubah ukurannya menjadi ukuran 50 x 70 . Citra selanjutnya akan diolah sehingga menghasilkan 140 data dengan nilai antara 0 dan 1 .

\subsection{Proses Pelatihan}

Secara umum, proses pelatihan dapat digambarkan dengan flowchart pada gambar 2 di bawah. 


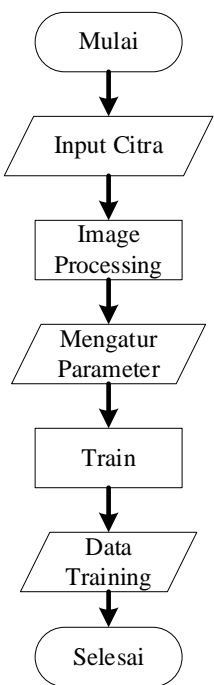

Gambar 2. Flowchart Prosedur Pelatihan

Proses pelatihan adalah memberi pengetahuan terhadap jaringan dengan data pembelajaran yang sesuai. Setelah jaringan saraf tiruan melewati tahap ini maka jaringan saraf tiruan telah siap digunakan untuk mengenali pola angka sesuai dengan pengetahuan yang dimilikinya dari proses pembelajaran tersebut. Pada jaringan saraf tiruan, pelatihan dilakukan dalam rangka melakukan pengaturan bobot, sehingga pada akhir pelatihan akan diperoleh bobot-bobot yang baik [5].

Selama proses pelatihan, bobot-bobot diatur secara iteratif untuk meminimumkan fungsi kerja jaringan. Fungsi kerja yang digunakan dalam membangun jaringan saraf tiruan pengenalan angka ini adalah mean square error (mse), fungsi ini akan mengambil rata-rata kuadrat error yang terjadi antara output jaringan dan target. Dan untuk diimplementasikan menggunakan Metode Backpropagation digunakan cara gradient descent dengan momentum dan adaptive Learning Rate (traingdx). Algoritma pelatihan dengan cara ini terdapat parameterparameter yang harus diset, yaitu:

a. Maksimum Epoh

Maksimum epoh adalah jumlah epoh maksimum yang boleh dilakukan selama proses pelatihan. Iterasi akan berhenti apabila nilai epoh melebihi maksimum epoh. Nilai default untuk maksimum epoh adalah 10 .

b. Kinerja Tujuan

Kinerja tujuan adalah target fungsi kinerja. Iterasi akan dihentikan apabila nilai fungsi kinerja kurang dari atau sama dengan kinerja tujuan. Nilai default untuk kinerja tujuan adalah 0 .

c. Learning Rate

Learning rate adalah laju pembelajaran. Semakin besar nilai learning rate akan berimplikasi pada semakin besarnya langkah pembelajaran. Jika learning rate diset terlalu besar, maka algoritma akan menjadi tidak stabil. Sebaliknya, jika learning rate diset terlalu kecil, maka algoritma akan konvergen dalam jangka waktu yang lama. Nilai default untuk learning rate adalah 0.01 .

d. Maksimum Kegagalan

Maksimum kegagalan diperlukan apabila pada algoritma disertai dengan validitas (optional). Maksimum kegagalan adalah ketidakvalidan terbesar yang diperbolehkan. Ketidakvalidan adalah kondisi saat hasil mean square error (mse) lebih besar dari mse iterasi sebelumnya. Apabila gradient iterasi ke-k lebih besar daripada gradient iterasi ke(k-1), maka kegagalannya akan bertambah 1 . Iterasi akan dihentika apabila jumlah kegagalan lebih dari nilai maksimum. Nilai default untuk maksimum kegagalan adalah 5.

\section{e. Gradient Minimum}

Gradient minimum adalah akar dari kuadrat semua gradient (bobot input, bobot lapisan, bobot bias) terkecil yang diperbolehkan. Iterasi akan dihentikan apabila nilai akar jumlah kuadrat semua gradient ini kurang dari gradient minimum. Nilai default untuk gradient minimum adalah 0.0000000001 .

\section{f. Momentum}

Sebuah parameter momentum tinggi dapat membantu dalam meningkatkan kecepatan konvergen. Namun, pengaturan parameter momentum yang terlalu tinggi dapat beresiko melampaui batas minimum yang dapat menyebabkan algoritma menjadi tidak stabil. Sebaliknya, jika momentum diset terlalu kecil, maka algoritma akan konvergen dalam waktu yang sangat lama.

Flowchart proses pelatihan menggunakan Backpropagation dapat dilihat pada gambar 3 di bawah. 


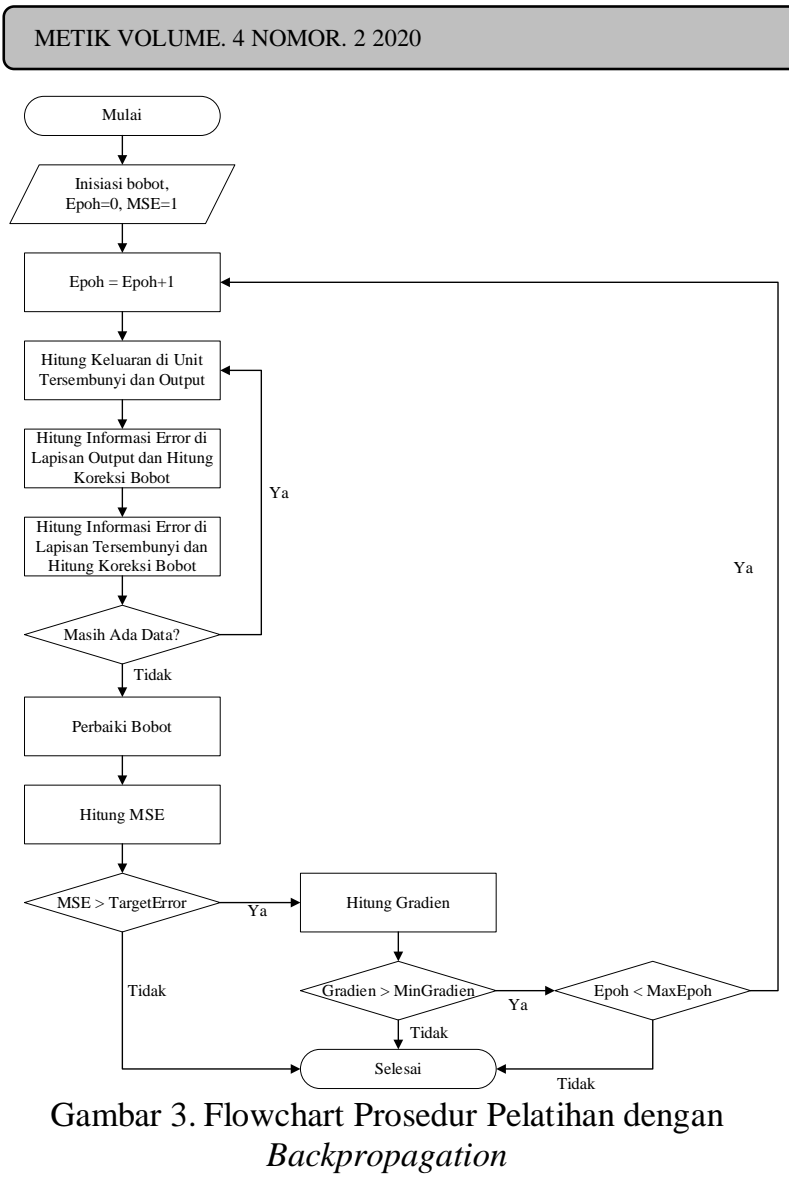

Prosedur pelatihan dengan Backpropagation dimulai dengan inisialisasi awal semua bobot. Inisialisasi bobot yang penulis gunakan dalam sistem pengenalan angka ini adalah inisialisasi bobot secara acak. Setelah bobot diinisialisasi, dimulai literasi pelatihan untuk menghitung setiap data input mengunakan fungsi aktivasi. Fungsi aktivasi yang digunakan adalah sigmoid biner. Selanjutnya dilakukan proses propagasi mundur, yaitu menghitung informasi error setiap unit output dan tersembunyi menggunakan turunan dari fungsi aktivasi sigmoid biner, serta menghitung koreksi setiap bobotnya. Setelah menghitung semua data input yang ada, maka tahap selanjutnya adalah mengubah setiap bobot dan menghitung mean square error (mse). Setelah didapatkan mse, maka akan dilakukan pengecekan hasil perhitungan mse dengan parameter kinerja tujuan yang telah ditentukan sebelumnya. Apabila nilai mse lebih kecil dari kinerja tujuan, maka proses pelatihan akan berhenti. Jika tidak, maka akan dihitung gradient, yaitu nilai akar dari kuadrat setiap bobot. Setelah didapatkan nilai gradient, maka akan dilakukan pengecekan nilai gradient dengan parameter gradient minimum yang telah ditentukan sebelumnya. Apabila nilai gradient lebih kecil dari nilai gradient minimum, maka proses pelatihan akan berhenti. Jika tidak maka akan dilakukan kembali pelatihan sampai didapat keluaran yang sesuai dengan parameter yang ditentukan atau sampai batas iterasi yang telah ditentukan.

\subsection{Proses Pengenalan}

Setelah melakukan pelatihan maka tahap selanjutnya adalah pengenalan. Proses ini akan melakukan pengenalan terhadap data yang masuk akan dikenali berdasarkan data yang telah melalui proses pembelajaran sebelumnya. Flowchart proses pengenalan digambarkan seperti pada gambar 4 di bawah.

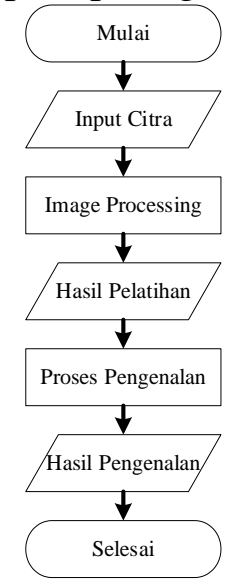

Gambar 4. Flowchart Prosedur Pengenalan

\section{Hasil Penelitian}

\subsection{Analisis}

Pada analisis ini, data pelatihan menggunakan 380 data input dan dengan uji coba terhadap Maksimum Epoh, Kinerja Tujuan (Goal), Maksimum Kegagalan, Gradient Minimum, Learning Rate (L R) dan Momentum (M C). Hasil pelatihan pada uji coba ini selanjutnya akan dilakukan simulasi menggunakan sebuah gambar yang sama.

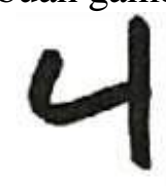

Gambar 5. Gambar Yang Digunakan dalam Analisis Pelatihan

Dari gambar 5 di atas akan diketahui seberapa tepat jaringan saraf tiruan yang dibangun dalam mengelani pola angka yang terdapat pada gambar tersebut. Pertama-tama program akan melakukan preprocessing 
image pada gambar 5 di atas menjadi seperti pada gambar 6 di bawah

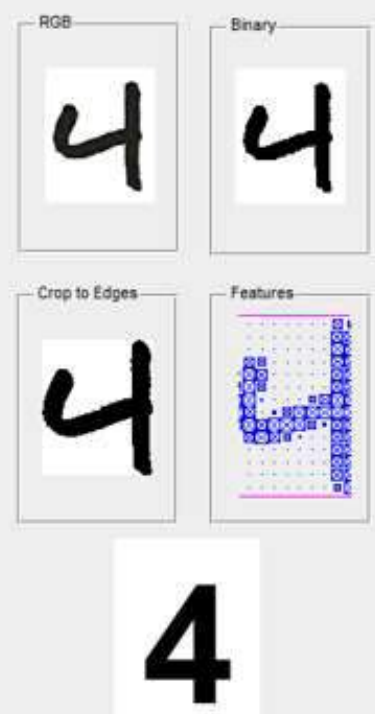

Gambar 6. Hasil Image Processing

Hasil dari proses pada gambar 6, jika ditampilkan dalam bentuk grafik pengenalannya seperti gambar 7 di bawah.

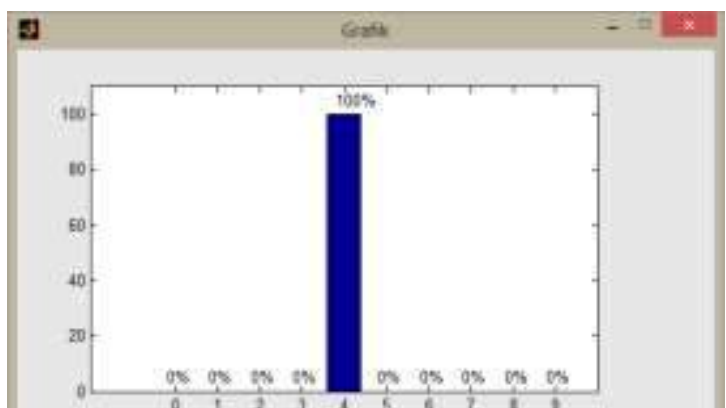

Gambar 7. Grafik Hasil Simulasi dengan Gambar 5.

Dari gambar 7, dapat dilihat bahwa proses pengenalannya menunjukkan angka 4 yang lebih dia kenali, sehingga output dari proses pengenalannya adalah 4 . Untuk dapat melakukan proses pengenalan, diperlukan proses pelatihan terlebih dahulu, proses pelatihan menggunakan form seperti gambar 8 di bawah

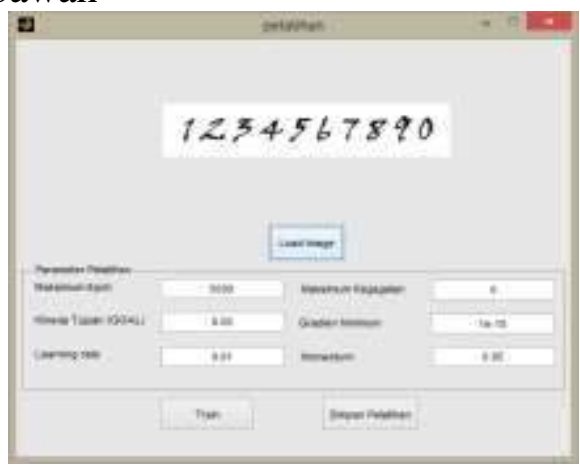

Gambar 8. Form Pelatihan
Selama proses pelatihan akan ditampilkan proses iterasi seperti pada gambar 9 di bawah.

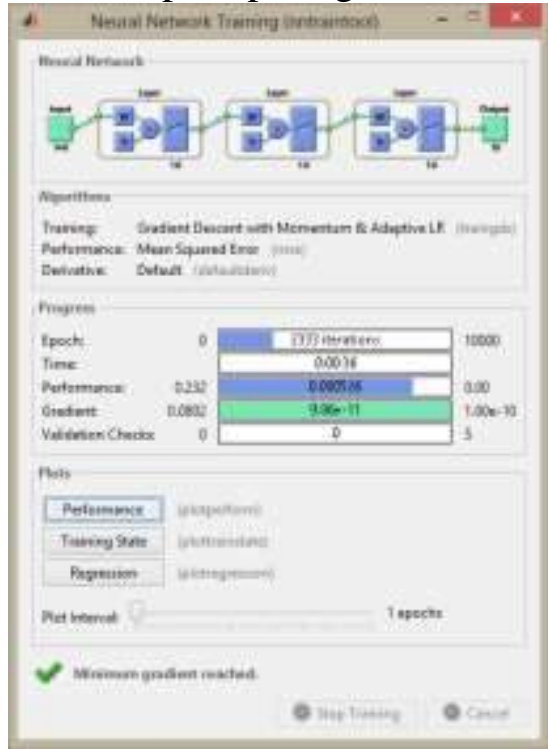

Gambar 9. Grafik Hasil Simulasi dengan Maksimum Epoh 100

1. Uji Coba dengan Maksimum Epoh

Tabel 1. Hasil Uji Coba Parameter Maksimum Epoh

\begin{tabular}{|c|c|c|c|c|c|c|c|c|}
\hline \multirow{2}{*}{$\begin{array}{c}\text { Maks } \\
\text { Epoh }\end{array}$} & $\begin{array}{c}\text { Kinerja } \\
\text { Tujuan } \\
\text { (Goal) }\end{array}$ & \multirow{2}{*}{$\begin{array}{c}\text { L R R } \\
\text { Kegag }\end{array}$} & $\begin{array}{c}\text { Min } \\
\text { alan }\end{array}$ & Gradient & \multicolumn{3}{|c|}{ Kondisi Saat Selesai } \\
\cline { 6 - 9 } & & & \multicolumn{3}{|c|}{ Pelatihan } \\
\hline 100 & $1 \mathrm{E}-06$ & 0,1 & 6 & $1 \mathrm{E}-10$ & 0,9 & 100 & 0.089475 & 0,005762 \\
\hline 500 & $1 \mathrm{E}-06$ & 0,1 & 6 & $1 \mathrm{E}-10$ & 0,9 & 500 & 0.000933 & $4,59 \mathrm{E}-05$ \\
\hline 1000 & $1 \mathrm{E}-06$ & 0,1 & 6 & $1 \mathrm{E}-10$ & 0,9 & 1000 & 0.000263 & $1,67 \mathrm{E}-08$ \\
\hline 5000 & $1 \mathrm{E}-06$ & 0,1 & 6 & $1 \mathrm{E}-10$ & 0,9 & 1105 & 0.000263 & $9,73 \mathrm{E}-11$ \\
\hline
\end{tabular}

Berikut ini grafik masing-masing hasil simulasi terhadap Gambar 5 menggunakan hasil pelatihan dengan parameter pada tabel 1 .

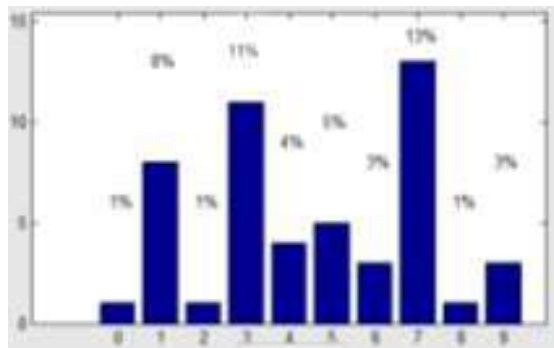

Gambar 10. Grafik Hasil Simulasi dengan Maksimum Epoh 100

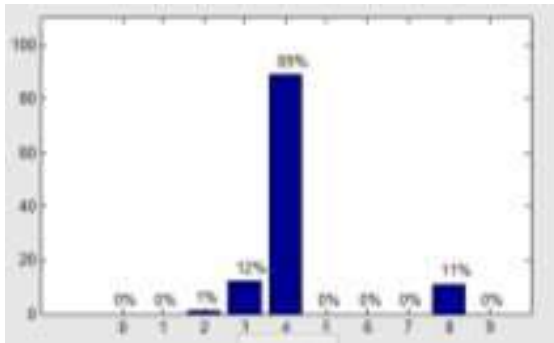

Gambar 11. Grafik Hasil Simulasi dengan Maksimum Epoh 500 


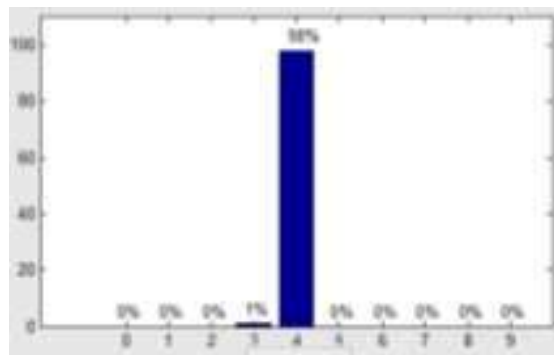

Gambar 12. Grafik Hasil Simulasi dengan Maksimum Epoh 1000

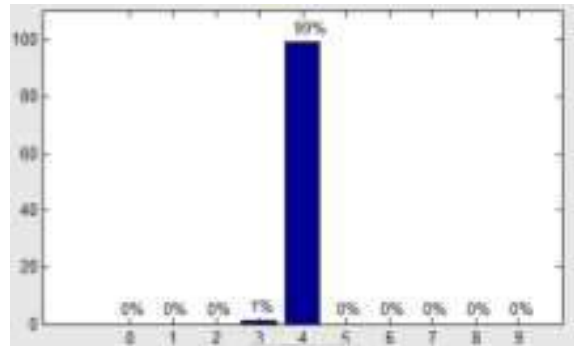

Gambar 13. Grafik Hasil Simulasi dengan Maksimum Epoh 5000

Dari tabel 1 dan Gambar 10 sampai Gambar 13 dapat diambil kesimpulan bahwa semakin kecil maksimum epoh yang di-input, maka proses iterasi akan lebih cepat selesai, ini dapat dilihat dari banyaknya epoh saat iterasi selesai. Namun dengan parameter maksimum epoh yang di-input terlalu kecil maka hasil pelatihan akan menjadi tidak stabil sehingga pada saat dilakukan simulasi, persentase keakuratan pengenalan menjadi lebih kecil. Sebalikya, bila parameter maksimum epoh yang di-input terlalu besar, maka lama iterasi akan dipengaruhi juga terhadap parameter yang lain, seperti parameter minimum gradient yang telah memenuhi kondisi saat iterasi ke 1105 ketika minimum gradient lebih besar dari gradient saat iterasi ke 1105 .

2. Uji Coba dengan Kinerja Tujuan

Tabel 2. Hasil Uji Coba Parameter Kinerja Tujuan

\begin{tabular}{|c|c|c|c|c|c|c|c|c|}
\hline Maks & \multirow{2}{*}{$\begin{array}{c}\text { Kinerja } \\
\text { Epoh }\end{array}$} & $\begin{array}{c}\text { Majuan } \\
\text { (Goal) }\end{array}$ & L R & $\begin{array}{c}\text { Maks } \\
\text { Kegag } \\
\text { alan }\end{array}$ & $\begin{array}{c}\text { Min } \\
\text { Gradient }\end{array}$ & M & \multicolumn{3}{|c|}{ Kondisi Saat Selesai } \\
\cline { 5 - 9 } & & & & & Epoh & Goal & Gradient \\
\hline 5000 & $1 \mathrm{E}-04$ & 0,1 & 6 & $1 \mathrm{E}-10$ & 0,9 & 1105 & 0.000263 & $9,73 \mathrm{E}-11$ \\
\hline 5000 & $1 \mathrm{E}-03$ & 0,1 & 6 & $1 \mathrm{E}-10$ & 0,9 & 453 & 0.000998 & 0,000239 \\
\hline 5000 & $1 \mathrm{E}-02$ & 0,1 & 6 & $1 \mathrm{E}-10$ & 0,9 & 346 & 0.009888 & 0,001508 \\
\hline 5000 & $1 \mathrm{E}-01$ & 0,1 & 6 & $1 \mathrm{E}-10$ & 0,9 & 74 & 0.099582 & 0,016782 \\
\hline
\end{tabular}

Berikut ini grafik masing-masing hasil simulasi terhadap gambar 5 menggunakan hasil pelatihan dengan parameter pada tabel 2 .

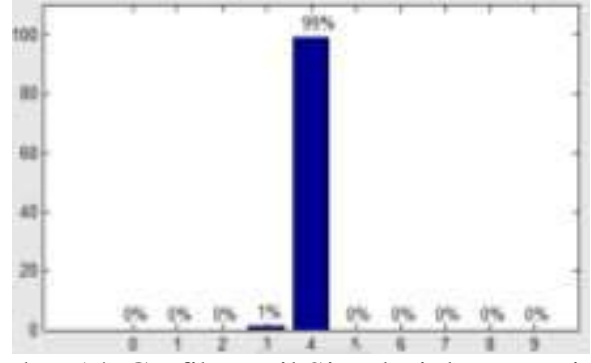

Gambar 14. Grafik Hasil Simulasi dengan Kinerja Tujuan $10^{-4}$

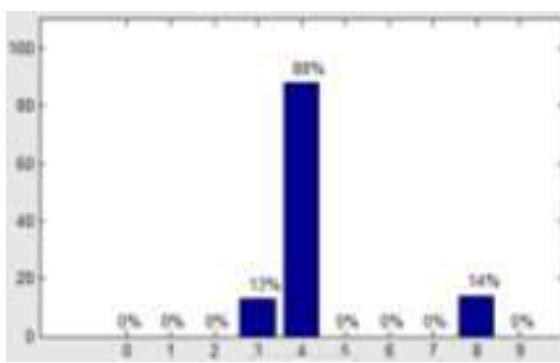

Gambar 15. Grafik Hasil Simulasi dengan Kinerja Tujuan $10^{-3}$

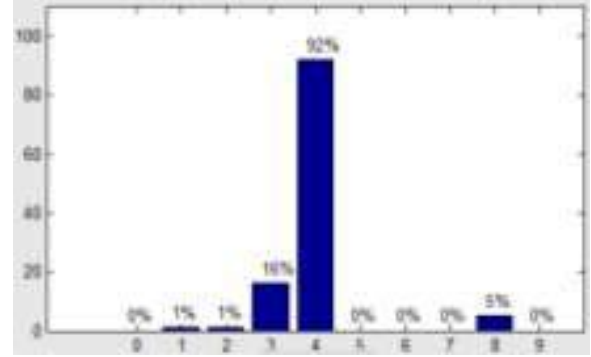

Gambar 16. Grafik Hasil Simulasi dengan Kinerja Tujuan $10^{-2}$

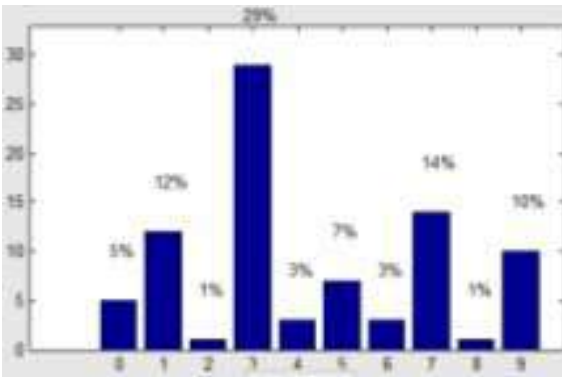

Gambar 17. Grafik Hasil Simulasi dengan Kinerja Tujuan $10^{-1}$

Dari tabel 2 dan gambar 14 sampai gambar 17 dapat diambil kesimpulan bahwa semakin besar kinerja tujuan yang di-input, maka proses iterasi akan lebih cepat selesai, ini dapat dilihat dari banyaknya epoh saat iterasi selesai. Namun dengan parameter kinerja tujuan yang di-input terlalu besar maka hasil pelatihan akan menjadi tidak stabil. Sebalikya, bila parameter kinerja tujuan yang di-input terlalu besar, maka lama iterasi akan dipengaruhi juga terhadap parameter yang 
lain, seperti parameter minimum gradient yang telah memenuhi kondisi saat iterasi ke 1105 ketika minimum gradient lebih besar dari gradient saat iterasi ke 1105 .

3. Uji Coba dengan Learning Rate

Tabel 3. Hasil Uji Coba Parameter Learning Rate

\begin{tabular}{|c|c|c|c|c|c|c|c|c|}
\hline \multirow{2}{*}{$\begin{array}{l}\text { Maks } \\
\text { Epoh }\end{array}$} & \multirow{2}{*}{$\begin{array}{l}\text { Kinerja } \\
\text { Tujuan } \\
\text { (Goal) }\end{array}$} & \multirow{2}{*}{ LR } & \multirow{2}{*}{$\begin{array}{l}\text { Maks } \\
\text { Kega } \\
\text { galan }\end{array}$} & \multirow{2}{*}{$\underset{\text { Mradient }}{\text { Min }}$} & \multirow{2}{*}{$\begin{array}{l}\mathrm{M} \\
\mathrm{C}\end{array}$} & \multicolumn{3}{|c|}{$\begin{array}{c}\text { Kondisi Saat Selesai } \\
\text { Pelatihan }\end{array}$} \\
\hline & & & & & & Epoh & Goal & Gradient \\
\hline 5000 & $1 \mathrm{E}-06$ & 0,9 & 6 & $1 \mathrm{E}-10$ & 0,9 & 1259 & $9,93 \mathrm{E}-07$ & $1,40 \mathrm{E}-06$ \\
\hline 5000 & $1 \mathrm{E}-06$ & 0,01 & 6 & $1 \mathrm{E}-10$ & 0,9 & 1108 & 0.000263 & $9,70 \mathrm{E}-11$ \\
\hline 5000 & $1 \mathrm{E}-06$ & 0,001 & 6 & $1 \mathrm{E}-10$ & 0,9 & 1237 & 0.000263 & $9,70 \mathrm{E}-11$ \\
\hline 5000 & $1 \mathrm{E}-06$ & 0,0001 & 6 & $1 \mathrm{E}-10$ & 0,9 & 1290 & 0.000263 & $9,58 \mathrm{E}-11$ \\
\hline
\end{tabular}

Berikut ini grafik masing-masing hasil simulasi terhadap gambar 5 menggunakan hasil pelatihan dengan parameter pada tabel 3 .

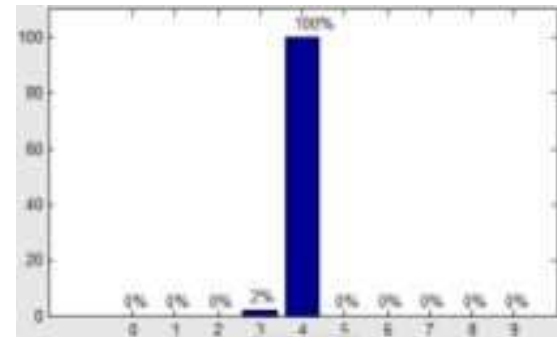

Gambar 18. Grafik Hasil Simulasi dengan Learning Rate 0,9

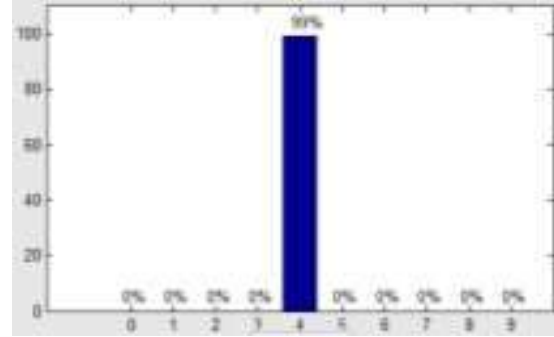

Gambar 19. Grafik Hasil Simulasi dengan Learning Rate 0,01

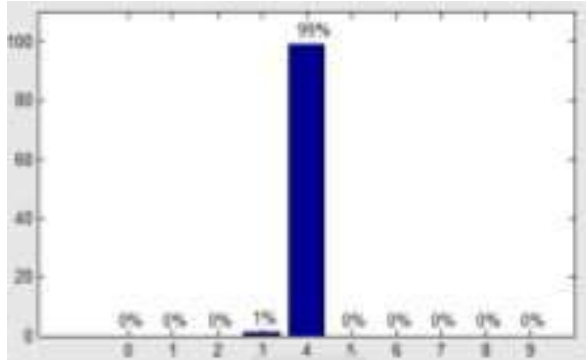

Gambar 20. Grafik Hasil Simulasi dengan Learning Rate 0,001

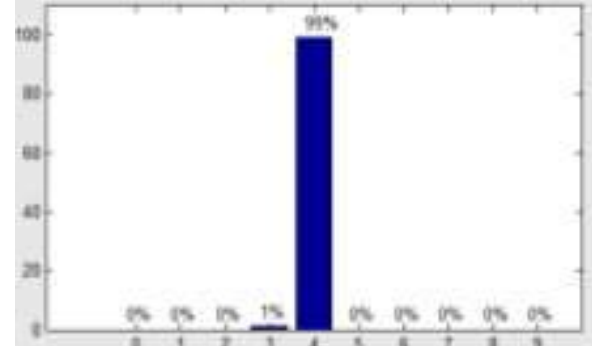

Gambar 21. Grafik Hasil Simulasi dengan Learning Rate 0,0001

Dari tabel 3 dan gambar 18 sampai gambar 21 dapat diambil kesimpulan bahwa parameter learning rate yang di-input akan mempengaruhi goal dan gradient pada setiap iterasi. Learning rate yang di-input terlalu besar akan menghasilkan goal yang semakin kecil setiap iterasinya tetapi perubahan gradient setiap iterasinya tidak terlalu besar.

4. Uji Coba dengan Maksimum Kegagalan Tabel 4. Hasil Uji Coba Parameter Maksimum Kegagalan

\begin{tabular}{|c|c|c|c|c|c|c|c|c|}
\hline $\begin{array}{c}\text { Kinerja } \\
\text { Tujuan } \\
\text { (Goal) }\end{array}$ & L R & $\begin{array}{c}\text { Maks } \\
\text { Kega } \\
\text { galan }\end{array}$ & $\begin{array}{c}\text { Min } \\
\text { Gradient }\end{array}$ & M C & \multicolumn{4}{|c|}{ Kondisi Saat Selesai Pelatihan } \\
\hline $1 E-06$ & 0,1 & 5 & $1 \mathrm{E}-10$ & 0,9 & 1105 & 0.000263 & $9,73 \mathrm{E}-11$ & 0 \\
\hline $1 \mathrm{E}-06$ & 0,1 & 4 & $1 \mathrm{E}-10$ & 0,9 & 1105 & 0.000263 & $9,73 \mathrm{E}-11$ & 0 \\
\hline $1 \mathrm{E}-06$ & 0,1 & 3 & $1 \mathrm{E}-10$ & 0,9 & 1105 & 0.000263 & $9,73 \mathrm{E}-11$ & 0 \\
\hline $1 \mathrm{E}-06$ & 0,1 & 2 & $1 \mathrm{E}-10$ & 0,9 & 1105 & 0.000263 & $9,73 \mathrm{E}-11$ & 0 \\
\hline
\end{tabular}

Dari tabel 4 dapat dilihat bahwa selama iterasi yang dilakukan tidak terdapat kegagalan yang terjadi, sehingga itersi berhenti ketika parameter yang lainnya telah memenuhi kondisi, yaitu ketika minimum gradient telah lebih dari gradient saat iterasi ke 1105.

5. Uji Coba dengan Minimum Gradient Tabel 5. Hasil Uji Coba Parameter Minimum Gradient

\begin{tabular}{|c|c|c|c|c|c|c|c|c|}
\hline \multirow{2}{*}{$\begin{array}{l}\text { Maks } \\
\text { Epoh }\end{array}$} & \multirow{2}{*}{$\begin{array}{l}\text { Kinerja } \\
\text { Tujuan } \\
\text { (Goal) }\end{array}$} & \multirow{2}{*}{ L R } & \multirow{2}{*}{$\begin{array}{l}\text { Maks } \\
\text { Kega } \\
\text { galan }\end{array}$} & \multirow{2}{*}{$\begin{array}{c}\text { Min } \\
\text { Gradient }\end{array}$} & \multirow{2}{*}{$\begin{array}{l}\mathrm{M} \\
\mathrm{C}\end{array}$} & \multicolumn{3}{|c|}{$\begin{array}{c}\text { Kondisi Saat Selesai } \\
\text { Pelatihan }\end{array}$} \\
\hline & & & & & & Epoh & Goal & Gradient \\
\hline 500 & & & 6 & & 0,9 & & & \\
\hline 5000 & & & 6 & & 0,9 & 553 & 0.000082 & \\
\hline 5000 & & & 6 & $1 \mathrm{E}-04$ & 0,9 & 409 & 0.001295 & $9,89 \mathrm{E}-0$ \\
\hline 5000 & $1 \mathrm{E}-06$ & 0,1 & 6 & $1 \mathrm{E}-03$ & 0,9 & 207 & 0.017842 & $9,89 \mathrm{E}-0$ \\
\hline
\end{tabular}

Berikut ini grafik masing-masing hasil simulasi terhadap gambar 5 menggunakan hasil pelatihan dengan parameter pada tabel 5 . 


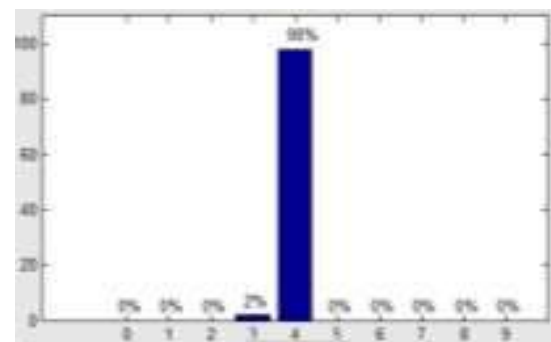

Gambar 22. Grafik Hasil Simulasi dengan Minimum Gradient $10^{-6}$

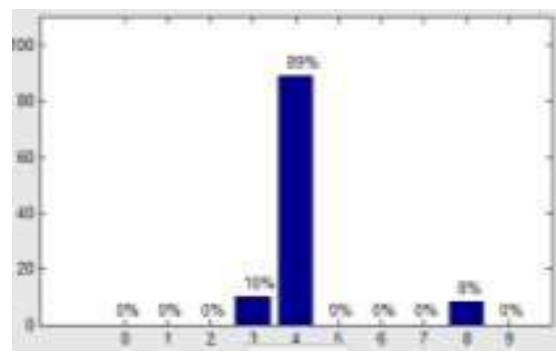

Gambar 23. Grafik Hasil Simulasi dengan Minimum Gradient $10^{-5}$

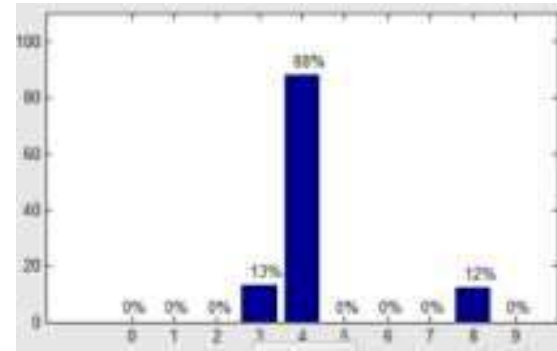

Gambar 24. Grafik Hasil Simulasi dengan Minimum Gradient $10^{-4}$

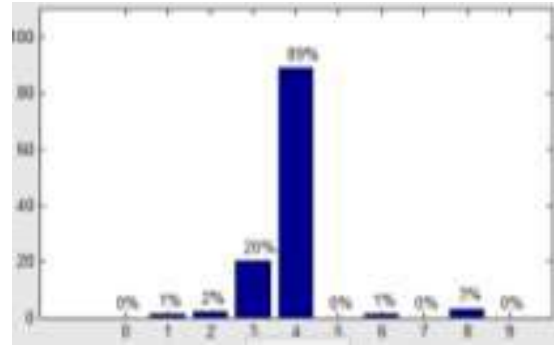

Gambar 25. Grafik Hasil Simulasi dengan Minimum Gradient $10^{-3}$

Dari tabel 5 dan gambar 22 sampai gambar 25 dapat dilihat bahwa apabila parameter minimum yang di-input terlalu kecil maka proses akan membutuhkan waktu yang lama untuk mencapai kondisi iterasi selesai, ini dapat dilihat dari banyaknya epoh yang dilakukan untuk mencapai kondisi berhenti. Sedangkan apabila parameter minimum yang di-input terlalu besar, maka akan berpengaruh terhadap hasil pelatihan yang menjadi tidak stabil, sebab iterasi telah berhenti ketika minimum gradient telah lebih dari gradien yang dihasilkan.

6. Uji Coba dengan Momentum
Tabel 6. Hasil Uji Coba Parameter Momentum

\begin{tabular}{|l|c|c|c|c|c|c|c|c|}
\hline \multirow{2}{*}{$\begin{array}{l}\text { Maks } \\
\text { Epoh }\end{array}$} & $\begin{array}{c}\text { Kinerja } \\
\text { Tujuan } \\
\text { (Goal) }\end{array}$ & L R & $\begin{array}{c}\text { Maks } \\
\text { Kega } \\
\text { galan }\end{array}$ & $\begin{array}{c}\text { Min } \\
\text { Gradient }\end{array}$ & M C & \multicolumn{3}{|c|}{\begin{tabular}{c} 
Kondisi Saat Selatihan \\
\cline { 5 - 9 }
\end{tabular}} \\
\hline 5000 & $1 \mathrm{E}-06$ & 0,1 & 6 & $1 \mathrm{E}-10$ & 0,1 & 1830 & 0.000530 & $9,90 \mathrm{E}-07$ \\
\hline 5000 & $1 \mathrm{E}-06$ & 0,1 & 6 & $1 \mathrm{E}-10$ & 0,05 & 1653 & 0.000793 & $9,97 \mathrm{E}-07$ \\
\hline 5000 & $1 \mathrm{E}-06$ & 0,1 & 6 & $1 \mathrm{E}-10$ & 0,01 & 1704 & 0.000793 & $9,96 \mathrm{E}-07$ \\
\hline 5000 & $1 \mathrm{E}-06$ & 0,1 & 6 & $1 \mathrm{E}-10$ & 0,005 & 1868 & 0.001056 & $9,98 \mathrm{E}-07$ \\
\hline
\end{tabular}

Berikut ini grafik masing-masing hasil simulasi terhadap gambar 5 menggunakan hasil pelatihan dengan parameter pada tabel 6 .

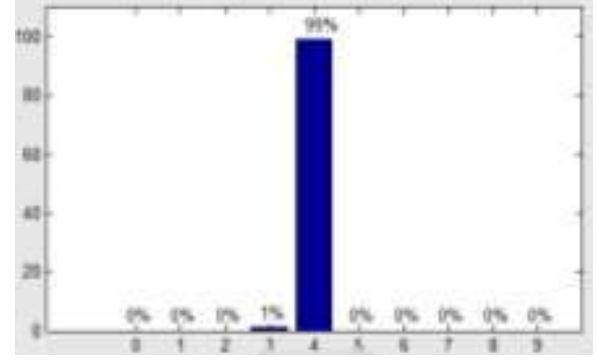

Gambar 26. Grafik Hasil Simulasi dengan Momentum 0,1

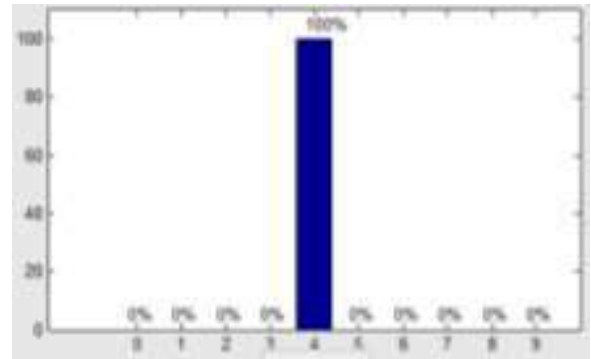

Gambar 27. Grafik Hasil Simulasi dengan Momentum 0,05

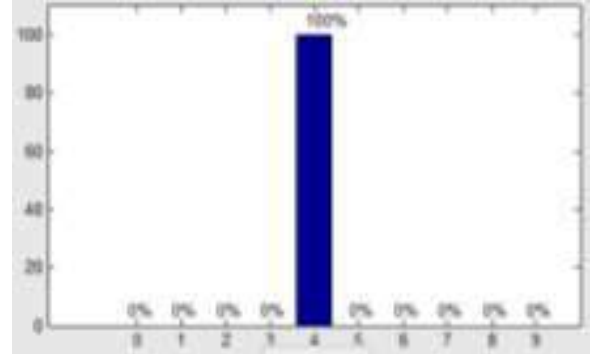

Gambar 28. Grafik Hasil Simulasi dengan Momentum 0,01

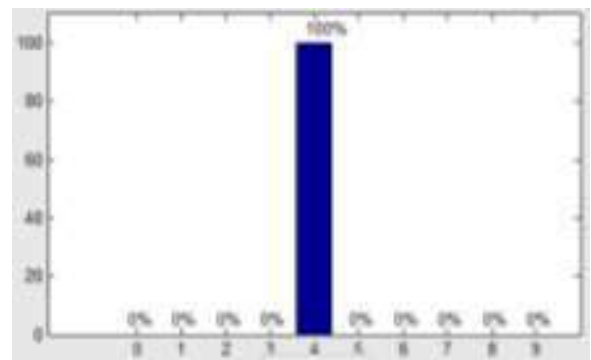

Gambar 29. Grafik Hasil Simulasi dengan Momentum 0,005 
Dari tabel 5 dan gambar 22 sampai gambar 25 dapat dilihat bahwa parameter momentum berpengaruh pada goal yang dihasilkan setiap iterasi. Parameter momentum yang di-input bila terlalu besar maka goal yang dihasilkan akan besar juga.

\section{Kesimpulan}

Dari analisa di atas dapat diambil kesimpulan bahwa parameter maksimum epoh, kinerja tujuan, dan gradient minimum mempengaruhi lamanya iterasi dilakukan, sedangkan parameter learning rate dan momentum berpengaruh terhadap goal yang dilakukan selama iterasi. Selain itu, semakin kecil goal saat iterasi selesai maka semakin besar persentase keakuratan pengenalan pola jaringan saraf tiruan yang dibangun. Pada jaringan saraf tiruan pengenalan angka menggunakan metode Backpropagation, tidak terdapat ketidakvalidan data pelatihan, sehingga kondisi mencapai maksimum kegagalan tidak pernah terjadi.

\section{Saran}

Diperlukan adanya penelitian lebih lanjut untuk melakukan uji coba dengan data masukan yang lebih banyak atau dengan menggunakan model jaringan saraf tiruan yang berbeda. Kedepannya juga penelitian dapat mengenali tidak hanya angka, tetapi dapat juga mengenali karakter atau tulisan lain.

\section{Daftar Pustaka}

[1] Suyanto, Artificial Intelligence:

Searching, Reasoning, Planning, dan

Learning. 2014.

[2] H. A. Fatta, Rekayasa Sistem

Pengenalan Wajah. Yogyakarta:

ANDI OFFSET, 2009.

[3] Y. Pangaribuan and M. Sagala, "Menerapkan Jaringan Saraf Tiruan untuk Mengenali Pola Huruf Menggunakan Metode Perceptron," Tek. Inform. Unika St. Thomas, 2017.

[4] F. Zola, "JARINGAN SYARAF TIRUAN MENGGUNAKAN

ALGORITMA

BACKPROPAGATION UNTUK

MEMPREDIKSI PRESTASI

SISWA," J. Teknol. DAN OPEN
SOURCE, 2018.

[5] A. Hermawan, Jaringan Saraf Tiruan. Yogyakarta: ANDI OFFSET, 2006. 